\title{
A Review on Topology, Operating and Control Methods of HVDC Transmission System for Offshore Wind Farms
}

\author{
Jinke Li ${ }^{1}$, Jingyuan Yin ${ }^{2,}$, Yonggao Guan ${ }^{1}$, Zhenquan Wang ${ }^{1}$, Tao Niu ${ }^{1}$, Hongning Zhen ${ }^{1}$, Zhikun Han ${ }^{1}$, Xueying Guo ${ }^{1}$ \\ ${ }^{1}$ China Energy Engineering Group Jiangsu Power Design Institute Co., LTD, Nanjing 211102, China \\ ${ }^{2}$ Institute of Electrical Engineering, Chinese Academy of Sciences, Beijing 100044, China
}

\begin{abstract}
High-voltage direct current (HVDC) transmission systems are a promising solution for long distances power transmission offshore wind farms. In order to satisfy the reliability requirements of receiving-end grid and system, the topology, operation and control of HVDC transmission systems for offshore wind farms should be paid more attention. Thus, the aim of this manuscript is to offer a comprehensive summary of existing topology, operation and control methods applied to HVDC transmission system for offshore wind farms. Special attention is provided to the ac grid fault through control methods, droop control methods, power sharing rules and specific requirements of HVDC system planning, model, design and investment. The results are important for understanding the operation of VSCHVDC in offshore wind farms.
\end{abstract}

\section{Introduction}

Recently, the energy problem has given rise to significant impacts on the life and production. Offshore winds have their advantages compared to onshore wind, which produce larger power. Due to the higher power and long distance transmission, DC transmission topology is currently the preferred for far offshore wind applications.

HVAC and HVDC transmission systems have been compared in many papers for offshore wind farms projects. Based on the fault recovery ability, reference [1] showed the advantage of HVDC compared to HVAC. Although HVAC has an advantage for small power plants (less than $300 \mathrm{MW}$ ), HVDC is more economical for a long distance transmission system[2]. Based on system loss, [3] studied that HVAC system is $12 \%$ more than HVDC for a long distance and large power plant system. Thus, the higher cost and device losses in maintenance are critical problems for traditional HVAC transmission for a long distance and large power wind farms. Reference [4] provided a novel transmission structure with ac cable and onshore converter. It is limited by the de grid scale and ability of the receivingend grid.

Due to large-scale development in short distance offshore wind resource, long distance and power wind plants are paid more and more attention to. Thus, HVDC transmission system is a pivotal element for offshore wind farms. VSC and LCC are two typical converters. Due to LCC cannot operate in island for an offshore converter, and LCC will bring frequent commutation failure for an onshore converter. LCCHVDC is inadaptable compared to VSC-HVDC in actual offshore wind farms projects. Extensive literatures introduce the operation and control methods of VSC-HVDC applied in actual projects. However, few literatures presents the VSC-HVDC for offshore windfarms. Thus, this paper will provide a comprehensive review for different VSC-HVDC topologies, operation strategies, and fault through methods.

\section{DC transmission topology and DC converter topology}

\subsection{DC transmission topology}

Captions should be typed in 9-point Times. They should be centred above the tables and flush left beneath the figures.

Fig. 1 shows simplified single line representations of DC transmission topologies. Five topologies existing in engineering or literatures are discussed in Table I. Point-to-point shown in Fig. 1(a) is a traditional transmission structure. Every wind farm has its offshore converter and dc line. It is easy to implement the protection configuration. Radial shown in Fig. 1(b) is also applied in actual project. Different wind farms are connected to a same offshore converter by ac cables. Radial+ shown in Fig. 1(c) is a novel structure which wind farms are connected to the offshore converter by dc cables. However the dc breaker has not been utilized in offshore wind farms, the cost and occupation is the key problem in the actual project. The ring structures shown in Fig. 1(d) and (e) achieve transmission flexibility, however the complicated protection

* Corresponding author: yinjingyuan@mail.iee.ac.cn 
configuration and high cost will limit the application in offshore wind farms.
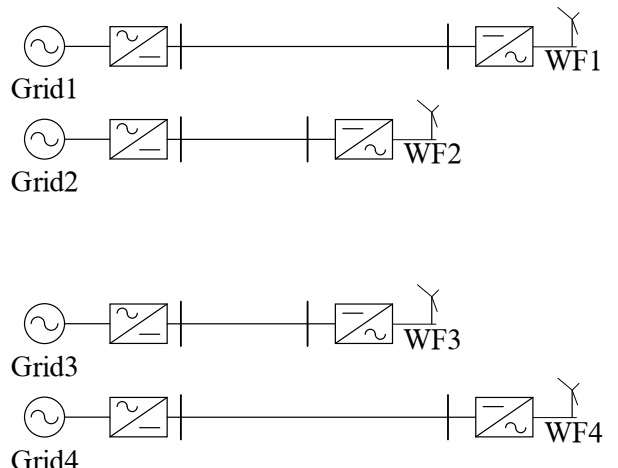

(a)
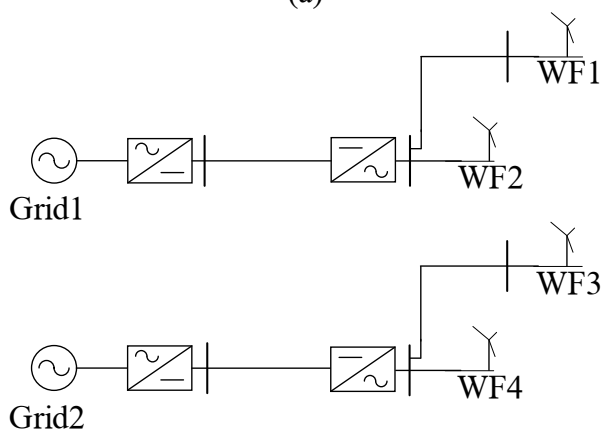

Grid2
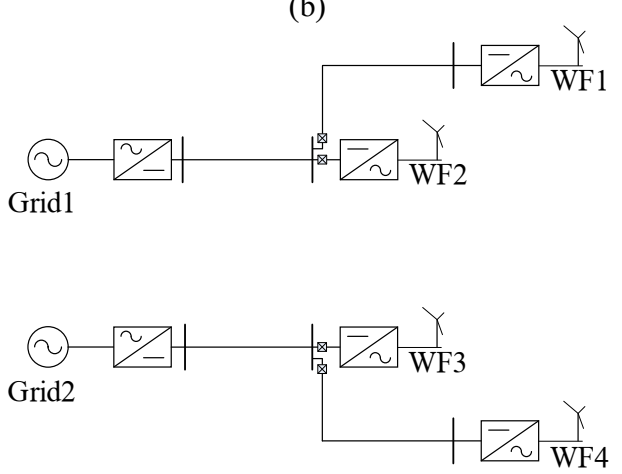

(c)

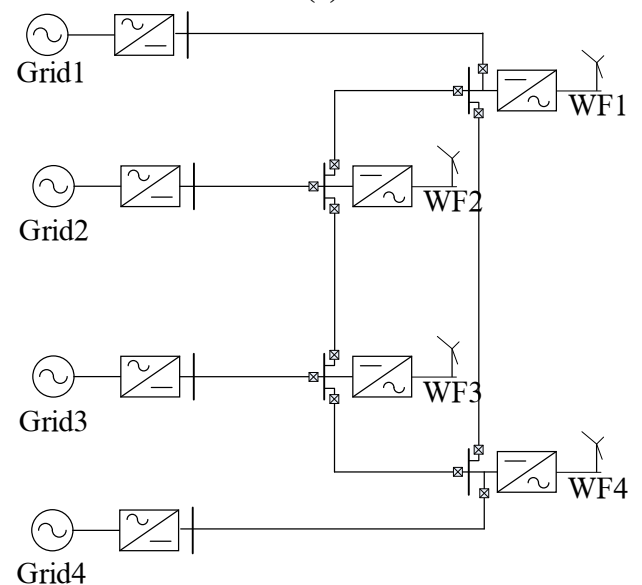

(d)

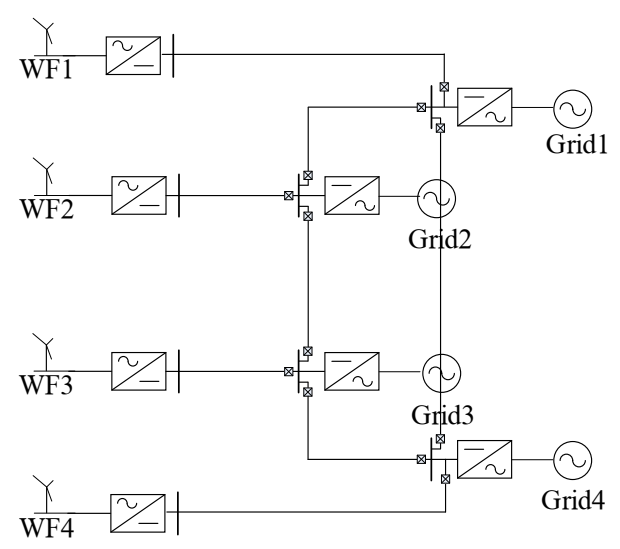

(e)

Figure 1: DC transmission topologies: a) point-to-point, b) radial, c) radial+, d) wind farm ring, e) substation ring

Table 1. Comparison of different DC transmission topologies

\begin{tabular}{|c|l|l|}
\hline Topology & \multicolumn{1}{|c|}{ advantages } & \multicolumn{1}{c|}{ disadvantages } \\
\hline $\begin{array}{c}\text { Point-to- } \\
\text { point [5] }\end{array}$ & $\begin{array}{l}\text { 1.Simplified } \\
\text { protection } \\
\text { configuration; } \\
\text { 2.engineering } \\
\text { application. }\end{array}$ & $\begin{array}{l}\text { 1.More dc cables and sea } \\
\text { area. }\end{array}$ \\
\hline Radial [3] & $\begin{array}{l}\text { 1.save resource } \\
\text { of dc cables and } \\
\text { sea area; } \\
\text { 2.engineering } \\
\text { application. }\end{array}$ & $\begin{array}{l}\text { 1.large occupation area } \\
\text { and high cost of offshore } \\
\text { converter; } \\
\text { 2.interacts with each WF. }\end{array}$ \\
\hline Radial+[5] & $\begin{array}{l}\text { 1. save resource } \\
\text { of dc cables and } \\
\text { sea area. }\end{array}$ & $\begin{array}{l}\text { 1.DC breaker } \\
\text { configuration. }\end{array}$ \\
\hline $\begin{array}{c}\text { Wind farm } \\
\text { ring [6] }\end{array}$ & $\begin{array}{l}\text { 1. offshore } \\
\text { transmission } \\
\text { flexibility. }\end{array}$ & $\begin{array}{l}\text { 1.dc breaker } \\
\text { configuration } \\
\text { 2.complicated protection } \\
\text { configuration; } \\
\text { 3. large occupation area } \\
\text { and high cost of offshore } \\
\text { converter. }\end{array}$ \\
\hline $\begin{array}{c}\text { Substation } \\
\text { ring [6] }\end{array}$ & $\begin{array}{l}\text { 1.dc breaker } \\
\text { grid flexibility. } \\
\text { configuration; } \\
\text { 2.complicated protection } \\
\text { configuration. }\end{array}$ \\
\hline
\end{tabular}

\subsection{DC converter topology}

In actual projects and existing literatures, MMC is the most conventional structure for offshore converter[5][7]. It has been applied in offshore wind farms engineering. Similar to $\mathrm{MMC}$, other high voltage and large power AC-DC converters, AAC[5] and LCC[8], are also proposed. But offshore LCC cannot operate in islanded, the wind farms cannot be charged by it. AAC has better dc fault blocking ability compared to MMC with half bridge submodule. But the control strategy is relatively complex. A DC-AC topology with series capacitorclamped module shown in Fig. 2(d) is proposed for offshore wind farms[9]. It achieves the minimal switching loss and maximum efficiency. However, the unused module topology brings the challenge for its application. Three DC-DC topologies are shown in Fig. 2 (a)-(c). Medium-voltage dc system shown in Fig. 2 (a) can eliminate the low-frequency heavy and large step- 
up transformers[10]. The topology shown in Fig. 2(b) achieves high system efficiency[10-13]. The modular impedance source shown in Fig. 2(c) has better faulttolerant ability.

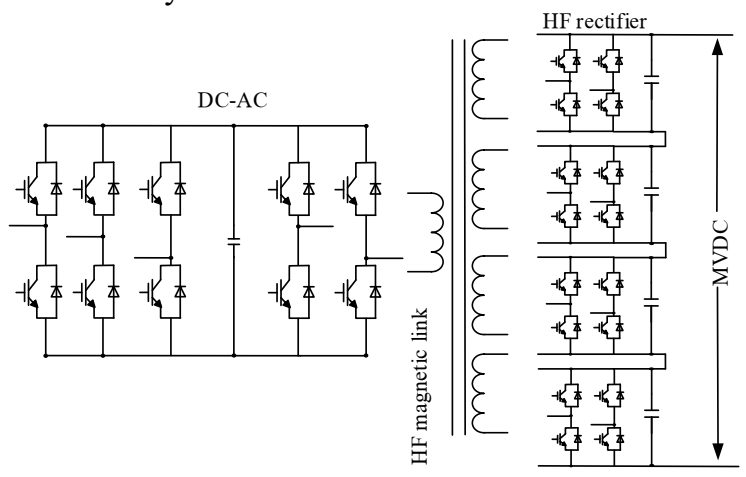

(a)

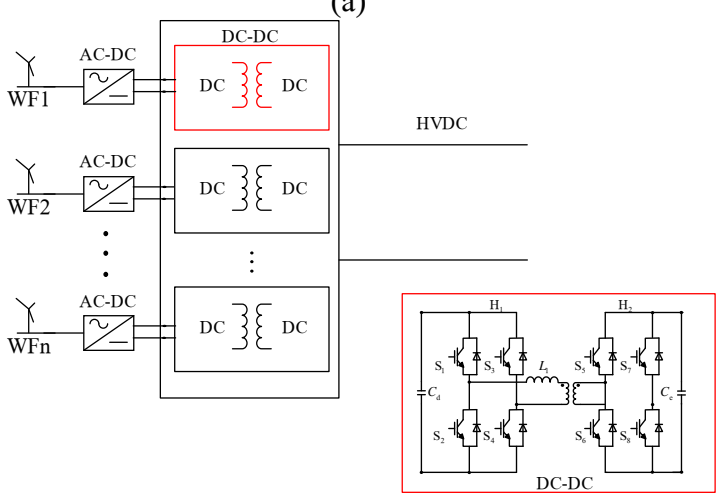

(b)

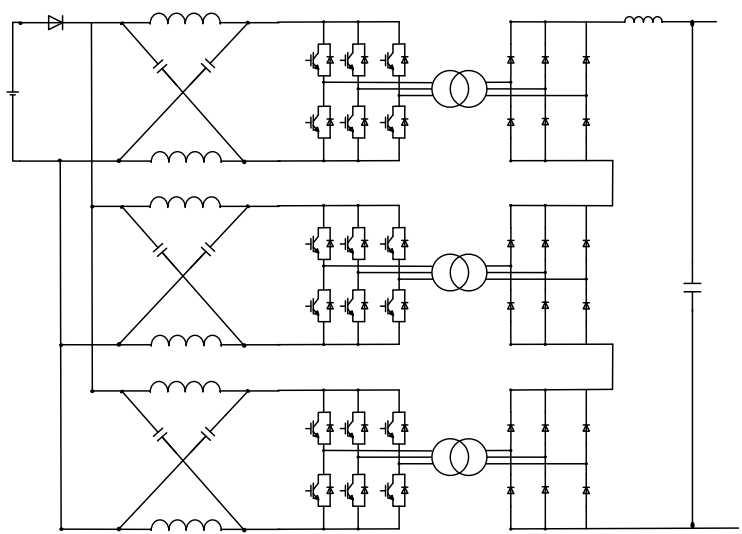

(c)

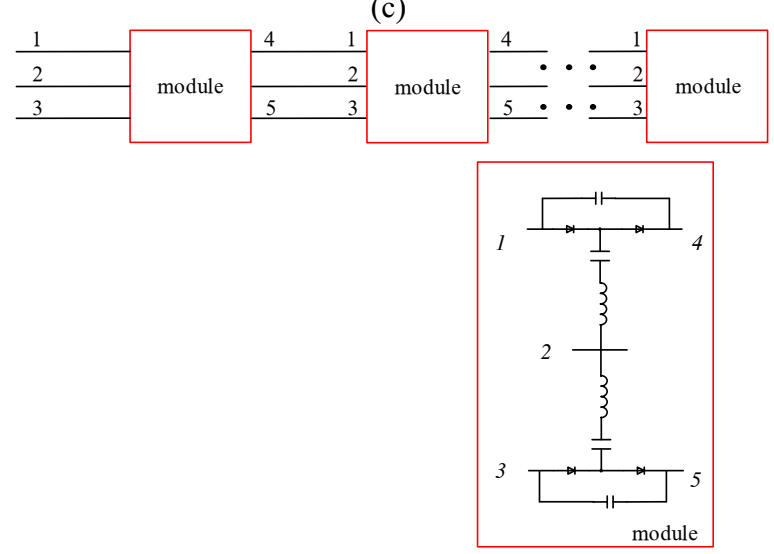

(d)

Figure 2: DC-DC converter topologies
Table 2. Comparison of different DC transmission topologies

\begin{tabular}{|c|c|c|}
\hline Topology & advantages & disadvantages \\
\hline $\begin{array}{l}\text { MMC }+ \text { half } \\
\text { bridge SM [5] }\end{array}$ & $\begin{array}{l}\text { 1. engineering } \\
\text { application }\end{array}$ & $\begin{array}{l}\text { 1. dc fault-tolerant } \\
\text { ability }\end{array}$ \\
\hline $\mathbf{A A C}[5]$ & $\begin{array}{l}\text { 1.dc fault } \\
\text { blocking ability }\end{array}$ & $\begin{array}{l}\text { 1. high system loss } \\
2 \text {, complex control } \\
\text { strategies }\end{array}$ \\
\hline $\mathrm{LCC}[8]$ & $\begin{array}{l}\text { 1.lower } \\
\text { investment }\end{array}$ & $\begin{array}{l}\text { 1. cannot operate } \\
\text { in isolated mode }\end{array}$ \\
\hline $\begin{array}{l}\text { Media-voltage } \\
\text { DAB converter } \\
\text { [9] }\end{array}$ & $\begin{array}{l}\text { 1.eliminate low- } \\
\text { frequency and } \\
\text { step-up } \\
\text { transformer } \\
\text { 2.supress } \\
\text { voltage } \\
\text { conversion } \\
\text { stages }\end{array}$ & $\begin{array}{l}\text { 1. more } \\
\text { construction cost } \\
\text { 2.complex control } \\
\text { strategies }\end{array}$ \\
\hline $\begin{array}{l}\text { DC-DC converter } \\
{[10-13]}\end{array}$ & $\begin{array}{l}\text { 1. high system } \\
\text { efficiency }\end{array}$ & $\begin{array}{l}\text { 1. more } \\
\text { construction cost } \\
\text { 2.complex control } \\
\text { strategies }\end{array}$ \\
\hline $\begin{array}{l}\text { modular } \\
\text { impedance source } \\
\text { DC-DC converter } \\
{[14]}\end{array}$ & $\begin{array}{l}\text { 1.fault-tolerant } \\
\text { ability } \\
\text { 2. lower cable } \\
\text { costs }\end{array}$ & $\begin{array}{l}\text { 1. more } \\
\text { construction cost } \\
\text { 2.complex control } \\
\text { strategies } \\
\text { 3.power quality }\end{array}$ \\
\hline $\begin{array}{l}\text { capacitor- } \\
\text { clamped module } \\
\text { DC-DC converter } \\
{[15]}\end{array}$ & $\begin{array}{l}\text { 1.better output } \\
\text { voltage } \\
\text { 2.high voltage } \\
\text { gain }\end{array}$ & $\begin{array}{l}\text { 1. more } \\
\text { construction cost } \\
\text { 2.complex control } \\
\text { strategies } \\
\text { 3.higher } \\
\text { investment }\end{array}$ \\
\hline
\end{tabular}

\section{Control methods}

\subsection{Fault ride through strategy}

DC bus fault and AC grid fault are common faults that converters should deal with for VSC-HVDC transmission offshore wind farms. Based on DC bus fault, [16] analyzed the influence of the wind power plant control methods on the MMC-HVDC system based on the detailed cable model. DC bus fault is a critical failure, thus, the additional equipment or control method is necessary for DC fault ride through. In addition to the dc bus fault blocking converter structure (for example AAC[5]), chopper resistor is a common way to handle the dc fault for traditional offshore converter. Instead of the chopper resistor, a flywheel energy storage system is designed in[17]. Fast wind power plant control method can also reduce the influence of dc bus fault[18].

For the AC grid fault, [19] introduced the fault ride through implementation, while analyzing the $\mathrm{AC}$ grid characteristics and fault power recovery rate. A nine switch converter is designed for ac grid fault ride through[20]. A new configuration of U-VSC-HVDC onshore converter structure is proposed in [21]. In addition to the new configurations, reactive current prioritizing method is also discussed to improve the transient stability and response during ac grid fault[22]. Meanwhile, a frequency droop control strategy is introduced for ac grid fault ride through by power 
reallocation[23]. A fault current injection method is also introduced to enhance the overcurrent protection[3]. The advantage and disadvantages of these methods are shown in Table III.

\subsection{Droop control and power sharing for multi- terminal HVDC}

In section 2.1, a series of DC transmission topologies are introduced. For solving the control issue of multiterminal ends in offshore windfarms, [24] forcused on the stability of MTDC and provided more interconnections for power grids and other forms of energy. Based on the stability of VSC-HVDC in windfarms, [25] investigated the stability consequences of offshore wind power into the existing Northwest European transmission system. In [26], a flexible DC transmission control method for offshore windfarms is introduced. It utilized DC voltage droop control for inverters and kept the dc voltage statble under some failure conditions. About droop control in VSC-HVDC for offshore windfarms, [27] also provided a droop control method to guarantee a safe operation while keeping the optimal operation of the DC grid. Compared to the droop control method proposed in [26] [27], [28] proposed a droop control strategy in terms of losses and reduced the system investments.

For the multiterminal-HVDC network in offshore windfarms, power sharing is also a key probelm. Reference [29] proposed a supervisory control method for multiterminal-HVDC offshore windfarms systems. It designed the sharing of the active power generated from offshore windfarms among onshore AC grids under normal operation conditions. Reference [30] designed a mixed-integer linear program for day-ahead scheduling problem with linearised AC optimal power flow and multiterminal-HVDC system models. For solving the power sahring based on fault conditions, [31] provides a power redistribution strategy to achieve a better frequency performance of the onshore $\mathrm{AC}$ grids.

\subsection{Special issues}

To analyze the offshore windfarms system more accurate, the mathematical model is a key problem. A simplified model of HVDC transmission system connecting offshore windfarms to AC grid is proposed in [32]. Based on a multiterminal-HVDC system, [33] uses small-signal analysis model to investigate the influence of control parameters and DC breakers.

For improving the HVDC system control performance, [34] introduces a system frequence regulation strategy based on a ancillary frequence controller in onshore converter without additional investments. Reference [35] utilizes the arm energy control strategy to achieve a better performance.

\section{Conclusions and future work}

The features of the offshore wind farms have made it an attractive research point for energy production and transmission. The demand to conform established rules has led to the development of VSC-HVDC topologies and control methods. This work presents a comprehensive review of the dc transmission topology, dc converter topology and fault ride through strategies for offshore wind farms. This review is important for understanding the operation of VSC-HVDC in offshore wind farms. In the future work, some operation performance and implementational methods in actual projects will be introduced and discussed.

\section{Acknowledgments}

This research work was supported by project funded by China Postdoctoral Science Foundation (2019M652028).

\section{References}

1. H. Liu and Z. Chen, "Contribution of VSC-HVDC to Frequency Regulation of Power Systems With Offshore Wind Generation," IEEE Transactions on Energy Conversion, vol. 30, no. 3, pp. 918-926, Sept. 2015.

2. A. Inamdar and A. Bhole, "Converters for HVDC Transmission for Offshore Wind Farms: A Review," in International Conference on Current Trends towards Converging Technologies (ICCTCT), Coimbatore, 2018, pp. 1-7.

3. Y. Jing, R. Li, L. Xu and Y. Wang, "Enhanced AC voltage and frequency control of offshore MMC station for wind farm connection," IET Renewable Power Generation, vol. 12, no. 15, pp.1771-1777, 2018.

4. E. Apostolaki-Iosifidou, R. Mccormack, W. Kempton, et al., "Transmission Design and Analysis for Large-Scale Offshore Wind Energy Development," IEEE Power and Energy Technology Systems Journal, vol. 6, no. 1, pp. 22-31, March 2019.

5. C. MacIver, K. R. W. Bell and D. P. Nedic, "A Reliability Evaluation of Offshore HVDC Grid Configuration Options," IEEE Transactions on Power Delivery, vol. 31, no. 2, pp. 810-819, Apr 2016.

6. [6]Raza A, Dianguo X, Xunwen S, et al. “A Novel Multiterminal VSC-HVdc Transmission Topology for Offshore Wind Farms". IEEE Transactions on Industry Applications, 2017, 53(2):1316-1325.

7. C. Lv and N. Tai, "Control for offshore wind power integration based on modular multilevel converter," The Journal of Engineering, vol. 2017, no. 13, pp. 1885-1889, 2017.

8. L. Yu, R. Li and L. Xu, "Distributed PLL-Based Control of Offshore Wind Turbines Connected With Diode-Rectifier-Based HVDC Systems," IEEE Transactions on Power Delivery, vol. 33, no. 3, pp. 1328-1336, June 2018. 
9. N. Nityanand and A. K. Pandey, "HVDC-Based Multilevel Modular Power Converter for Offshore Wind Farms," in International Conference on Power Energy, Environment and Intelligent Control (PEEIC), Greater Noida, India, 2018, pp. 540-544.

10. Beik O , Schofield N . "An Off-Shore Wind Generation Scheme With High Voltage Hybrid Generator, HVDC Interconnections and Transmission". IEEE Transactions on Power Delivery, 2015, 31(2):1-1.

11. Z. Nie, L. Shi, Y. Zhao and Y. Ni, "Impacts on operational characteristics of AC/DC system with different grid integration modes of offshore wind farm via MMC-based HVDC transmission," The Journal of Engineering, vol. 2019, no. 16, pp. 1900$1905,2019$.

12. Liang Z, An W, Dan Z, et al. "Modular multi-level converter designed for DC-based offshore wind farm" in Power Electronics \& Application Conference \& Exposition. 2015.

13. M. A. Bahmani, T. Thiringer, A. Rabiei and T. Abdulahovic, "Comparative Study of a Multi-MW High-Power Density DC Transformer With an Optimized High-Frequency Magnetics in All-DC Offshore Wind Farm," IEEE Transactions on Power Delivery, vol. 31, no. 2, pp. 857-866, Apr, 2016.

14. M. R. Islam, M. A. Rahman, K. M. Muttaqi and D. Sutanto, "A New Magnetic-Linked Converter for Grid Integration of Offshore Wind Turbines Through MVDC Transmission," IEEE Transactions on Applied Superconductivity, vol. 29, no. 2, pp. 1-5, March 2019.

15. R. T. Naayagi and S. K. Panda, "Fault-tolerant converter for future offshore wind farm HVDC networks," in IEEE Innovative Smart Grid Technologies - Asia (ISGT-Asia), Auckland, 2017, pp. 1-5.

16. Vidal-Albalate $\mathrm{R}$, Beltran $\mathrm{H}$, Rolan A, et al. "Analysis of the Performance of MMC under Fault Conditions in HVDC-based Off-shore Wind Farms" IEEE Transactions on Power Delivery, 2016, 31(2):839-847.

17. M. I. Daoud, A. M. Massoud, A. S. Abdel-Khalik, et al "A Flywheel Energy Storage System for Fault Ride Through Support of Grid-Connected VSC HVDC-Based Offshore Wind Farms," IEEE Transactions on Power Systems, vol. 31, no. 3, pp. 1671-1680, May 2016.

18. Ramtharan G, Arulampalam A, Ekanayake J B, et al. "Fault ride through of fully rated converter wind turbines with AC and DC transmission" Iet Renewable Power Generation, 2009, 3(4):426-0.

19. A. A. van der Meer, M. Ndreko, M. Gibescu, et al."The Effect of FRT Behavior of VSC-HVDCConnected Offshore Wind Power Plants on AC/DC System Dynamics," IEEE Transactions on Power Delivery, vol. 31, no. 2, pp. 878-887, Apr 2016.

20. A. Kirakosyan, M. S. E. Moursi and V. Khadkikar, "Fault Ride Through and Grid Support Topology for the VSC-HVDC Connected Offshore Wind Farms," IEEE Transactions on Power Delivery, vol.32, no. 3, pp. 1592-1604, Jun 2017.

21. Moawwad, M. S. El Moursi and W. Xiao, "Advanced Fault Ride-Through Management Scheme for VSC-HVDC Connecting Offshore Wind Farms," IEEE Transactions on Power Systems, vol. 31, no. 6, pp. 4923-4934, Nov. 2016.

22. M. Ndreko, M. Popov, J. C. Boemer, et al."Sensitivity analysis on short-circuit current contribution from VSC-HVDC systems connecting far and large offshore wind power plants," in IEEE PES Innovative Smart Grid Technologies, Europe, Istanbul, 2014, pp. 1-6.

23. D. I. Sortsi, S. I. Gkavanoudis and C. S. Demoulias, "Interconnection of offshore wind farms using variable frequency in offshore AC grids," in 51st International Universities Power Engineering Conference (UPEC), Coimbra, 2016, pp. 1-6.

24. Cao J, Du W, Wang H F . VSC-based HVDC power transmission for the large-scale offshore wind power - a survey[C]// International Conference on Renewable Power Generation. IET, 2016.

25. A. A. van der Meer, M. Ndreko, J. A. Bos, et al, "Stability assessment of VSC-HVDC connected large-scale offshore wind power: A North-Sea region case study," 2015 IEEE Eindhoven PowerTech, Eindhoven, 2015, pp. 1-6.

26. Qiu S, Chunju F, Cheng L, et al. Research on VSC -HVDC control strategy based on large offshore wind power system[J]. The Journal of Engineering, 2017, 2017(13):1923-1927.

27. Oriol, Gomis-Bellmunt, Agusti, et al. Droop control for loss minimization in HVDC multi-terminal transmission systems for large offshore wind farms[J]. Electric Power Systems Research, 2014.

28. Araguees-Penalba M, Egea-Alvarez A, GomisBellmunt $\mathrm{O}$, et al. Optimum voltage control for loss minimization in HVDC multi-terminal transmission systems for large offshore wind farms[J]. Electric power systems research, 2012, 89:p.54-63.

29. M. Abdelwahed, H. Sindi and E. F. El-Saadany, "Power sharing control and wind power curtailing for offshore multi-terminal VSC-HVDC transmission," 2016 IEEE Smart Energy Grid Engineering (SEGE), Oshawa, ON, 2016, pp. 141146.

30. Ahmad, Nikoobakht, Jamshid, et al. Towards robust OPF solution strategy for the future $\mathrm{AC} / \mathrm{DC}$ grids: case of VSC-HVDC-connected offshore wind farms[J]. IET Renewable Power Generation, 2018.

31. H. Dong, Z. Xu, P. Song, et al, "Optimized Power Redistribution of Offshore Wind Farms Integrated VSC-MTDC Transmissions After Onshore Converter Outage," in IEEE Transactions on Industrial Electronics, vol. 64, no. 11, pp. 89488958, Nov. 2017. 
32. E. Jahan, M. R. Hazari, M. Rosyadi, et al, "Simplified model of HVDC transmission system connecting offshore wind farm to onshore grid," 2017 IEEE Manchester PowerTech, Manchester, 2017, pp. 1-6.

33. J. Beerten, S. D'Arco and J. A. Suul, "Identification and Small-Signal Analysis of Interaction Modes in VSC MTDC Systems," in IEEE Transactions on Power Delivery, vol. 31, no. 2, pp. 888-897, April 2016.

34. H. Liu and Z. Chen, "Contribution of VSC-HVDC to Frequency Regulation of Power Systems With Offshore Wind Generation," in IEEE Transactions on Energy Conversion, vol. 30, no. 3, pp. 918-926, Sept. 2015.

35. S. Wenig, F. Rojas, K. Schönleber, et al, "Simulation Framework for DC Grid Control and ACDC Interaction Studies Based on Modular Multilevel Converters," in IEEE Transactions on Power Delivery, vol. 31, no. 2, pp. 780-788, April 2016. 